\title{
Report on a Unique Population of Ridgeback Shrimp, Solenocera choprai Nataraj 1945, in the Mid-shelf of West Coast of India with Present Status of Their Exploitation and Future Options for Management
}

\author{
A.P. DINESHBABU ${ }^{1 *}$ and J.K. MANISSERY ${ }^{2}$ \\ ${ }^{1}$ Mangalore Research Centre \\ Central Marine Fisheries Research Institute \\ Mangalore-575 001, India \\ ${ }^{2}$ Department of Aquaculture \\ College of Fisheries \\ Mangalore-575 002, India
}

\begin{abstract}
The trawl catch of the commercially important Solenocerid shrimp, Solenocera choprai caught from the sandy belt prevailing beyond the inner continental shelf west coast of India was studied. This population was noticed for the first time in 1993 and a regular fishery of the species established with increasing catch until 2003 when the catch showed a sharp reduction and continuing decline. In 2002 the landing was 3,186 $\mathrm{t}$ and in succeeding years the catch dropped to 1,445 and $752 \mathrm{t}$. The mean sizes of males and females also reduced. Stock assessment was carried out during the declining phase of the fishery (2003-2004). MSY for the period was estimated at 1,225 $\mathrm{t}$ using the length-based Thompson and Bell prediction model. The relative $Y / R$ showed that the $E_{\max }$ of 0.65 (against the present $E$ of 0.59 ) indicates further scope of increasing the fishing effort. However, the Thompson and Bell model indicated that any subsequent addition of effort from the present level will give comparatively low additional yield and the present fishery stands at the MEY level. For the success of the fishery in future years, it is recommended that the catch be restricted to the present estimated MSY level and continuous monitoring of the species be carried out to formulate corrective measures to check the declining trend.
\end{abstract}

\footnotetext{
* Corresponding author. Tel.: +91 0824 2447790; Fax: +91 08242424061

E-mail address: dineshbabuap@yahoo.co.in
} 


\section{Introduction}

Until 1990, trawling operations along the west coast of India were restricted to the inner continental shelf (within $30 \mathrm{~m}$ ) and catches consisted of species belonging to the genera, Parapenaeopsis, Metapenaeus and Penaeus. From 1993 onwards, the introduction of night trawling and multiday trawling resulted in trawling beyond the inner shelf and the emergence of non-conventional shrimp species belonging to the genera, Solenocera, Trachypenaeus, and Parapenaeus among others. The most important species in terms of quantity was Solenocera choprai (Nataraj, 1945). This species is caught along Mangalore coast (southwest coast of India) from a depth of 60 to $100 \mathrm{~m}$. Even though the species is widely distributed in the Indo-Pacific (Dall 1999), the magnitude of the population observed off the west coast of India has not been reported from any other part of the world. Hashimi et al. (1978), Harkantra et al. (1980), Kidwai et al. (1981) and Shankar and Karbassi (1992) found that there is a strip of sandy bottom off South Karnataka extending from a depth of 50 to $200 \mathrm{~m}$. Chan (1998) stated that $S$. choprai was found on soft bottoms at depths between 50 and $175 \mathrm{~m}$ probably burrowing in the mud during daytime, with only its tubelike antennular flagella sticking out.

The percentage contribution of $S$. choprai in the total penaeid shrimp landings of Mangalore coast during 1993 was 2.6\% and steadily increased to $50 \%$ by 2002 . In 2003 the catch showed a sharp reduction and continuing decline. In 2002 the landing was 3,186 t which, in succeeding years, dropped to 1,445 then 752 t. This depletion necessitated an in-depth study of the stock to understand whether the present rate of exploitation is affecting this resource. The species is very important commercially for both domestic and export supply. Although the unit price for shrimp is low when compared with other larger coastal shrimps, the quantity landed is so huge the species has considerable impact on the fishery economics of the coast. In the year 2002 alone, catch of the species was equivalent to US\$ 1.8 million (Rupees (Rs) 90 million). The species is also ecologically important as it has been reported to be present in the guts of many of the commercially important demersal fish species along the coast, thus it plays a major role in the trophic interactions of this ecosystem. The results of the present study and the knowledge about the present exploitation rate will enable policy makers to formulate strategies for management and for sustainable exploitation of this emerging resource, which contributes substantially to the fishery economy of the coast. 


\section{Materials and methods}

To understand the population dynamics of $S$. choprai of the Karnataka coast, catch data of the species during the last ten years were collected and analysed (Radhakrishnan et al. 2007). The species exploited from this fishing zone are landed only at two fishing harbours, Mangalore and Malpe. Data on catch and effort from the commercial trawlers operated from these harbours were used in the analysis. The data were collected on an average of 8 days (2 days a week) per month during 2003-2004. Monthly estimates of catch and effort of shrimps landed were based on the method described by Alagaraja (1984). Samples were collected and analysed for length-composition data. The monthly length-composition data from these harbours were pooled and used for the estimation of stock parameters and further for stock assessment of the species. The details regarding the area of fishing, depth of fishing, time of fishing, details of net and GPS readings of the fishing area were collected from selected commercial trawlers.

Stock parameter estimates of $S$. choprai were based on the lengthfrequency distribution data collected during the period of study. Specimens were brought to the laboratory on each day of observation, sexed and length and weight measurements were recorded. The length-frequency data were grouped into $5 \mathrm{~mm}$ class intervals (e.g. 46-50, 51-55, 56-60 etc. with mid-points at 48, 53 and 58 respectively). The length-frequency distribution in the sample was raised to the total catch on the sampling day based on the sample weights. The data thus obtained for different sampling in a month were pooled to get catch in numbers for all the sampling days which in turn, were raised to the monthly catch. The length-frequency from the Mangalore and Malpe fisheries harbours were pooled for the analysis. The length-frequency data were analysed using FiSAT software (Gayanilo and Pauly 1997) for growth and mortality parameters.

The growth parameters, $L_{\infty}=120 \mathrm{~mm}, K=1.18 \mathrm{yr}^{-1}$ and $t_{0}=-0.038$ (Dineshbabu and Manissery 2007) were taken as inputs for the present study. The total mortality coefficient $(Z)$ was estimated from the lengthfrequency data for the years 2003 and 2004 by using length-converted catch curve method of Pauly (1983) from the FiSAT routine. The natural mortality coefficient of $S$. choprai was calculated by Srinath's empirical formula (Srinath 1990). 
The instantaneous fishing mortality coefficient $(F)$ was computed from $F=Z-M$ relationship and exploitation ratio $(E)$ from equation,

$$
E=\frac{F}{Z}=\frac{F}{M+F}
$$

where $\mathrm{M}$ is the natural mortality coefficient and $\mathrm{Z}$ is the annual total mortality coefficient.

The standing stock, recruitment and length group-wise mortality rates, probability of capture by length and $\mathrm{E}_{\max }$ were estimated by routines as given in FiSAT. The annual stock size and standing stock under steady state conditions were estimated using Baranove's catch equation and MSY was calculated by using the length-based Thompson and Bell (1934) model. The Thompson and Bell model and relative yield-per-recruit $\left(Y^{\prime} / R\right)$ model by Beverton and Holt (1964) were used for deriving management options.

\section{Results}

\section{Fishing ground}

S. choprai was caught from 60 to $100 \mathrm{~m}$ depth off Mangalore and from the GPS readings collected from commercial trawlers, it was seen that the fishing area was between $74.10^{\circ}$ to $74.50^{\circ} \mathrm{E}$ and $12.50^{\circ}$ to $13.20^{\circ}$ $\mathrm{N}$ (Fig. 1). The fishing ground has a sandy bottom suited to the burrowing habit of $S$. choprai. Associated species found in this stratum were the shrimp, Parapenaeus fissuroides indicus and the finfish, Nemipterus mesoprion.

\section{Crafts and gears employed}

$S$. choprai was caught in trawl nets operated from mechanised vessels. Multi-day fleet (MDF) trawlers of 9.75-15 m overall length (OAL) (36-52 footer) fitted with engines of 53-102 hp made trips lasting up to 7 to 8 days. For the $S$. choprai fishery the fishermen use shrimp trawl nets which were slightly modified from the regular shrimp trawls by adding more lead weights to the foot rope at closer intervals than those used for other shrimps. Some fishermen attached iron chains to disturb the shrimps out of their burrows. Fishermen found that the catch is poor during the day compared to the night and trawling for $S$. choprai is now conducted in- 
variably during the night to exploit their nocturnal habit. The cod-end mesh size of shrimp net was $18-20 \mathrm{~mm}$.

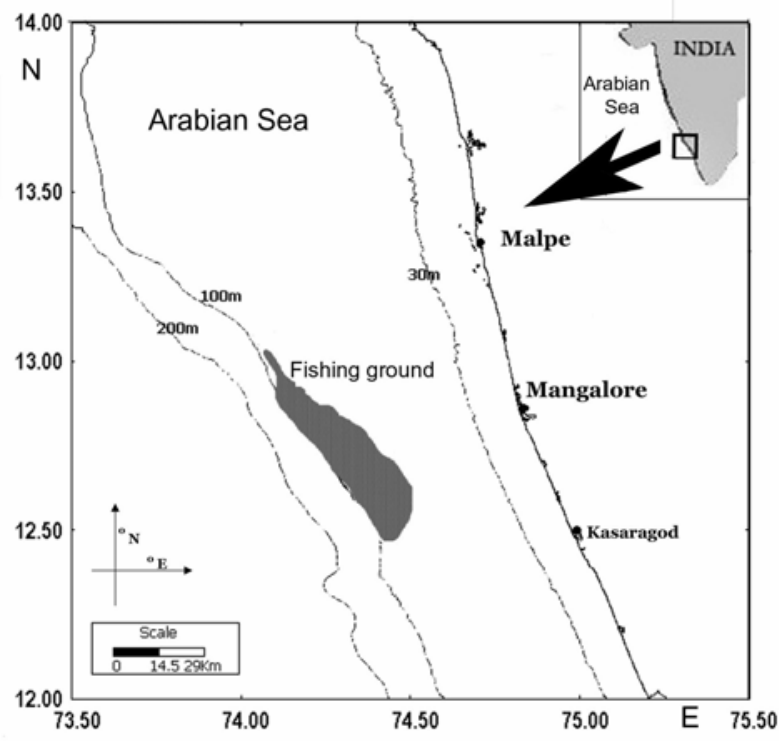

Figure 1. Map showing the fishing ground for Solenocera choprai

\section{Fishery}

Along the Karnataka coast $S$. choprai made an impact in the fishery economy from 1993 onwards. During 1993, the landing was about $8 \mathrm{t}$ which has increased to 3,186 t by 2002 (Table 1). This species was landed only at Mangalore and Malpe fisheries harbours with the majority of the landings (87\%) in Mangalore. The annual average landing of $S$. choprai during 1993-2002 was 586 t contributing $28.20 \%$ of the penaeid shrimp catch. The percent contribution of $S$. choprai to the shrimp fishery was less than $1 \%$ in 1993 and rose to $56.60 \%$ by 2002. In 2003 the landing was $1,445 \mathrm{t}$, a reduction of 55\% compared to the landing of 2002 (3,186 t). During 2004, landing was $752 \mathrm{t}$ showing a further reduction of about $693 \mathrm{t}$.

\section{Seasonal variations in the landing}

Overall, peak production of $S$. choprai along the Mangalore-Malpe coast is during the post-monsoon season (August-September). In 2003, the highest monthly landing was recorded in September and October and thereafter the catch decreased gradually till December. During August, the entire shrimp catch of the coast was constituted exclusively by $S$. choprai. 
Table 1. S. choprai landing at Mangalore and Malpe fisheries harbours during 1993-2002

\begin{tabular}{cccccc}
\hline \multirow{2}{*}{ Year } & \multicolumn{3}{c}{ Mangalore } & \multicolumn{3}{c}{ Malpe } & Total \\
\cline { 2 - 6 } & landing $(\mathrm{t})$ & $\%$ & landing $(\mathrm{t})$ & $\%$ & landing $(\mathrm{t})$ \\
\hline 1993 & 8 & 100 & 0 & 0 & 8 \\
1994 & 101 & 100 & 0 & 0 & 101 \\
1995 & 172 & 100 & 0 & 0 & 172 \\
1996 & 164 & 98 & 3 & 2 & 168 \\
1997 & 258 & 92 & 21 & 8 & 280 \\
1998 & 228 & 76 & 74 & 24 & 301 \\
1999 & 368 & 98 & 8 & 2 & 376 \\
2000 & 498 & 92 & 42 & 8 & 541 \\
2001 & 1551 & 84 & 291 & 16 & 1841 \\
2002 & 2746 & 86 & 440 & 14 & 3186 \\
2003 & 1243 & 86 & 202 & 14 & 1445 \\
2004 & 734 & 98 & 18 & 2 & 752 \\
\hline
\end{tabular}

During January another peak in landings was observed which again declined gradually (Fig. 2). In 2004 a similar trend was observed, with the highest landing in September (442 t) and the catch declining thereafter.

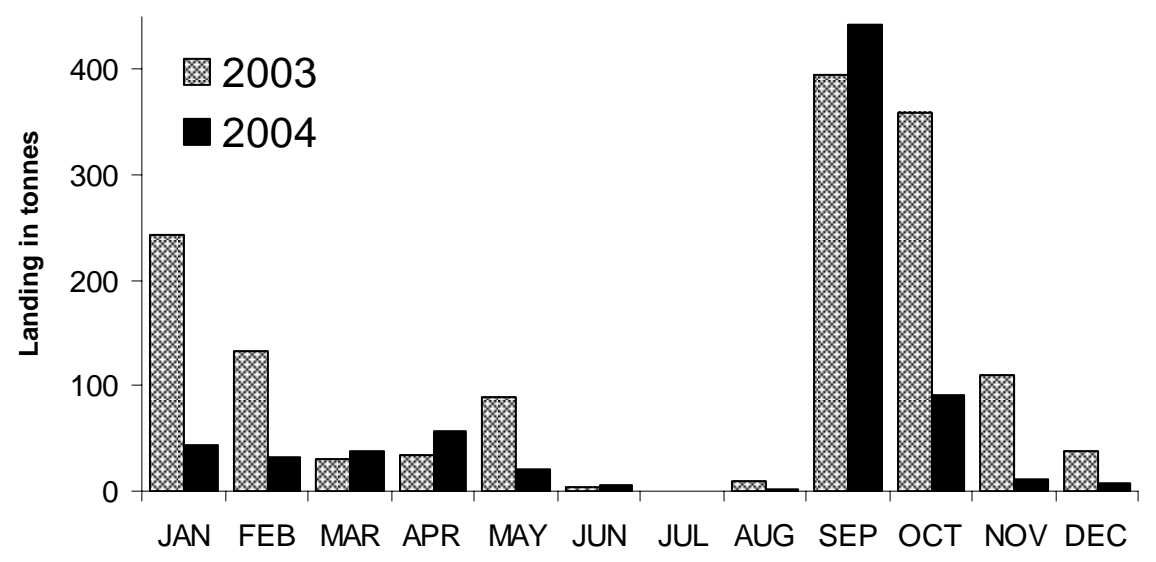

Figure 2. Month-wise landing of $S$. choprai at Mangalore and Malpe fisheries harbours during 2003and 2004

\section{Size range and mean size}

The total length of males ranged from 46 to $95 \mathrm{~mm}$, with the 76-80 $\mathrm{mm}$ size range dominating the fishery in 2003 and the $71-80 \mathrm{~mm}$ size range in 2004. The mean length of males was $74 \mathrm{~mm}$ in 2003, and $72 \mathrm{~mm}$ in 2004. In the case of females, their lengths ranged from 50 to $110 \mathrm{~mm}$ during 2003-2004. The maximum number was caught in the 91-95 mm size class in 2003 and $81-85 \mathrm{~mm}$ size class in 2004. Here also there was a 
reduction in mean size. The mean size in 2003 was $86.3 \mathrm{~mm}$ dropping to $82.7 \mathrm{~mm}$ in 2004 . When data for both sexes were pooled, the maximum number was caught in the length range of 71-85 mm in 2003 and 65-85 $\mathrm{mm}$ in 2004, confirming that smaller sized shrimps dominated the fishery in the later year.

\section{Mortality parameters}

The annual total mortality coefficient $(Z)$ estimated for the period 2003-2004 was 5.31 (Fig. 3). Natural mortality coefficient $(M)$ value estimated by Srinaths' formula was 2.20 and the fishing mortality coefficient $(F)$ calculated from these values was 3.11.

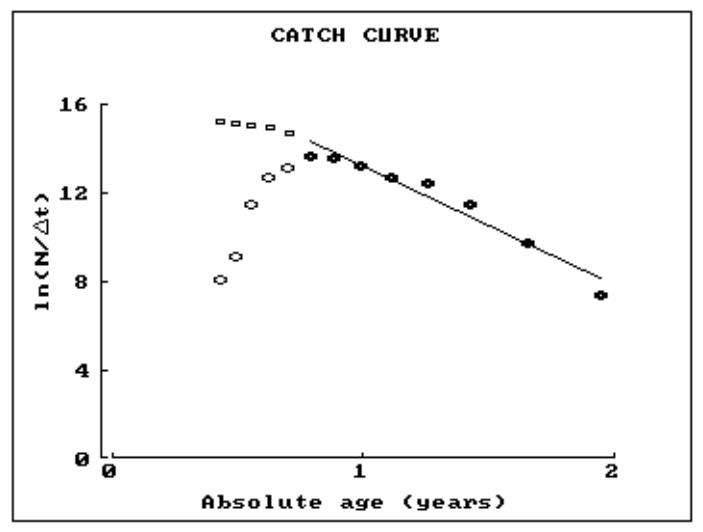

\begin{tabular}{|c|c|}
\hline Solenocera choprai, & $2003-04$ \\
\hline 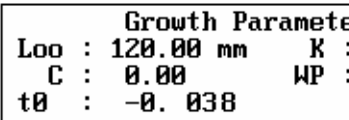 & $\begin{array}{l}\text { ers } \\
: \quad 1.18\end{array}$ \\
\hline $\begin{array}{l}\text { cutoff length (L') } \\
\text { mean length (from L') } \\
\text { Z from catch curve } \\
\text { Z entered } \\
\text { natural mortality } \\
\text { (M, for } T=26^{\circ}{ }^{\circ} \text { ) } \\
\text { Malue used } \\
\text { fishing mortality (F=2 } \\
\text { ( } \& \text { \& as entered) } \\
\text { exploit. rate (E=F/Z) }\end{array}$ & $\begin{array}{l}=70.580 \\
=82.769 \\
=5.31 \\
=\quad 5.31 \\
=2.48 \\
=2.20 \\
2-M) \\
=\quad 3.11 \\
=\quad 0.59\end{array}$ \\
\hline
\end{tabular}

Figure 3. Estimation of exploitation rate of S. choprai during 2003-2004 using Pauly's linearised length-converted catch curve method (FiSAT output)

\section{Probabilities of capture, length at first capture $\left(l_{c}\right)$ and age at cap- ture $\left(T_{c}\right)$}

The selection values obtained by the probability of capture method were $L_{25}=64.89 \mathrm{~mm}, L_{50}=68.83 \mathrm{~mm}$ and $L_{75}=73.07 \mathrm{~mm}$. These values were used as inputs in the Thompson and Bell yield prediction analysis. The exploitation rate $(U)$ for the period was estimated at 0.58 . The exploitation ratio $(E)$ was 0.59 (Table 2 ). The age at capture $\left(T_{c}\right)$ was 0.75 years.

\section{Standing stock and MSY}

The yield $(Y)$ of $S$. choprai obtained from the coast by trawl was 1,445 $\mathrm{t}$ in 2003 and $752 \mathrm{t}$ in 2004 (Table 1). The estimated total stock for the period was 1,893 t (Table 2). The standing stock for the years 2003 and 2004 were estimated at 439 and 362 t, respectively. The MSY of $S$. choprai 
for 2003-2004 was calculated as 1,225 t using the length-based Thompson and Bell prediction model (Table 2).

Table 2. Estimated values of various parameters used for the stock estimation of S. choprai

\begin{tabular}{lr}
\hline \multicolumn{2}{c}{ Year/parameters } \\
\hline Total mortality $(Z)$ & 5.31 \\
Natural mortality $(M)$ & 2.20 \\
Fishing mortality $(F)$ & 3.11 \\
Exploitation ratio $(E)$ & 0.59 \\
Exploitation rate $(U)$ & 0.58 \\
Yield $(\mathrm{t})(Y)$ & 1,098 \\
Total stock $(\mathrm{t})(Y / U)$ & 1,893 \\
Standing stock $(\mathrm{t})(Y / F)$ & 353 \\
MSY by Thompson and Bell model $(\mathrm{t})$ & 1,225 \\
\hline
\end{tabular}

\section{Virtual population analysis (VPA)}

The pooled length-frequency data for the two years show that $F$ increases to a maximum of 5.04 at 95-99 mm length (Table 3). The mean numbers, the length-wise catch and the steady state biomass pertaining to each length class showed the catch consisted mainly of the $70-94 \mathrm{~mm}$ length group and the maximum catch (191.88 t) was obtained in the size class of 80-84 mm. The yield increased from $0.70 \mathrm{t}$ in the $45-49 \mathrm{~mm}$ size class to the maximum of $191.88 \mathrm{t}$ in the $80-84 \mathrm{~mm}$ size class and gradually reduced to $4.73 \mathrm{t}$ in the $105 \mathrm{~mm}+$ size class.

\section{Length-based Thompson and Bell model}

The average market price of $S$. choprai for different size classes was used for estimation of maximum sustainable economic yield (MEY) in the Thompson and Bell routine. The price ranged from Rs 2 per kg for 45$54 \mathrm{~mm}$ size to a maximum of Rs 40 per kg for shrimps of length $105 \mathrm{~mm}$ and above. The analysis showed that MEY of Rs 23.20 million is obtained by the present level of fishing. The average yield of $S$. choprai for the period 2003-2004 calculated from the length-based Thompson and Bell prediction model was 1,070 $\mathrm{t}$ and the maximum sustainable yield (MSY) calculated from this is 1,225 t. As in the Thompson and Bell prediction model (Fig. 4), any subsequent addition of effort from the present level (i.e. 100 to $120 \%, 120$ to $140 \%$ and 140 to $160 \%$ ), will result in comparatively very low additional yields (3.46, 2.44 and 1.76\%, respectively) (Table 4). In light of these results, it appears that there is no scope for increasing the fishing effort to achieve higher economic yield. By analyzing shrimp landing data it was observed that the average annual fishing effort expended by multi-day trawlers from Mangalore-Malpe fisheries 
harbours during 2003-2004 was 18.16 million fishing hours resulting in an average annual landing of 1,098 t.

Table 3. Details of the estimation of yield, average biomass and average value of $S$. choprai for 2003-2004 using length-based cohort analysis

\begin{tabular}{|c|c|c|c|c|c|c|c|c|c|}
\hline $\begin{array}{l}\text { Lower } \\
\text { size- } \\
\text { limit } \\
(\mathrm{mm})\end{array}$ & $\begin{array}{c}\text { Numbers } \\
\text { caught } \\
\text { ('000) }\end{array}$ & $\begin{array}{l}\text { Number } \\
\text { of } \\
\text { survivors } \\
\text { ('000) }\end{array}$ & $F / Z$ & $F$ & $Z$ & $\begin{array}{l}\text { Mean } \\
\text { weight } \\
\text { (gm) }\end{array}$ & $\begin{array}{l}\text { Mean } \\
\text { number } \\
\text { ('000) }\end{array}$ & $\begin{array}{l}\text { Yield } \\
\text { (t) }\end{array}$ & $\begin{array}{l}\text { Aver. } \\
\text { value } \\
\text { (Rs/kg) }\end{array}$ \\
\hline 45 & 72.01 & 601007 & 0.00 & 0.00 & 2.20 & 1.04 & 32972 & 0.07 & 2 \\
\hline 50 & 225.31 & 528397 & 0.00 & 0.01 & 2.21 & 1.84 & 30988 & 0.41 & 2 \\
\hline 55 & 2868.59 & 459999 & 0.04 & 0.10 & 2.30 & 2.43 & 28893 & 6.97 & 5 \\
\hline 60 & 9904.63 & 393567 & 0.15 & 0.37 & 2.57 & 3.14 & 26439 & 31.10 & 5 \\
\hline 65 & 17690.29 & 325497 & 0.26 & 0.76 & 2.96 & 3.98 & 23404 & 70.34 & 10 \\
\hline 70 & 29420.94 & 256319 & 0.41 & 1.51 & 3.71 & 4.95 & 19528 & 145.66 & 10 \\
\hline 75 & 28729.27 & 183937 & 0.46 & 1.90 & 4.10 & 6.07 & 15126 & 174.53 & 20 \\
\hline 80 & 26072.35 & 121931 & 0.52 & 2.41 & 4.61 & 7.36 & 10827 & 191.88 & 20 \\
\hline 85 & 17554.89 & 72038 & 0.53 & 2.47 & 4.67 & 8.82 & 7111 & 154.76 & 30 \\
\hline 90 & 16544.77 & 38839 & 0.66 & 4.23 & 6.43 & 10.45 & 3912 & 172.97 & 30 \\
\hline 95 & 7462.54 & 13688 & 0.70 & 5.04 & 7.24 & 12.29 & 1480 & 91.69 & 30 \\
\hline 100 & 1729.03 & 2968 & 0.68 & 4.61 & 6.81 & 14.33 & 375 & 24.77 & 30 \\
\hline 105 & 248.19 & 414 & 0.60 & 3.30 & 5.50 & 19.06 & 75 & 4.73 & 40 \\
\hline Total & & 2998599 & & & & & 201129 & 1069.89 & \\
\hline \multicolumn{10}{|c|}{ These results were obtained using the parameters: } \\
\hline & $K$ & 1.18 & & & & \multicolumn{3}{|l|}{$q$} & $9.7 \mathrm{E}-06$ \\
\hline & $L_{\infty}$ & $120 \mathrm{~mm}$ & & & & \multirow{3}{*}{\multicolumn{3}{|c|}{ Terminal exploitation rate }} & 3.06821 \\
\hline & $M$ & 2.20 & & & & & & & 0.60 \\
\hline & $M / 2 K$ & 0.93 & & & & & & & \\
\hline
\end{tabular}

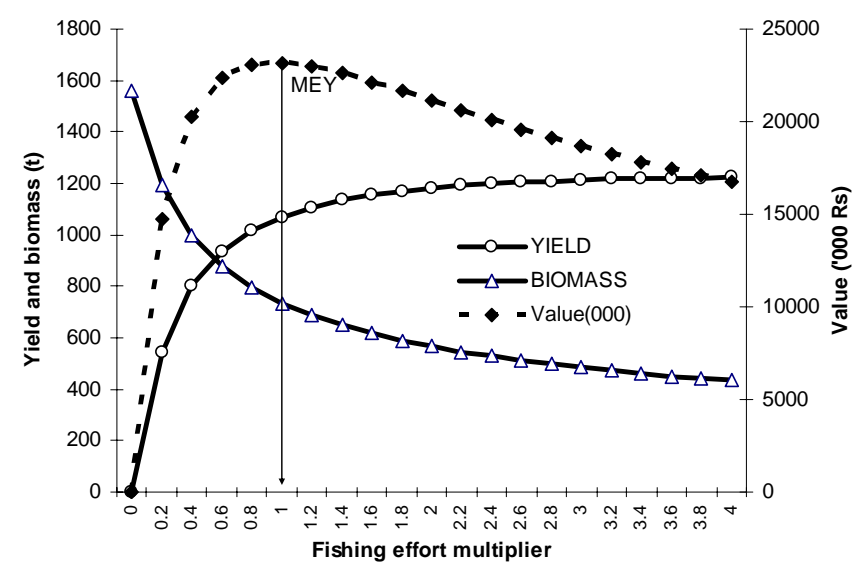

Figure 4. Results of Thompson and Bell analysis for S. choprai with length-frequency data pooled for 2003-2004 
Table 4. Yield, average biomass and value derived from length-based Thompson and Bell analysis

\begin{tabular}{ccccrr}
\hline $\begin{array}{c}\text { Effort } \\
\text { multiplier } \\
(\mathrm{X})\end{array}$ & $\begin{array}{c}\text { Yield } \\
(\mathrm{t})\end{array}$ & $\begin{array}{c}\text { Average } \\
\text { biomass } \\
(\mathrm{t})\end{array}$ & $\begin{array}{c}\text { Value ('000) } \\
(\mathrm{Rs})\end{array}$ & $\begin{array}{c}\text { Additional } \\
\text { yield } \\
(\%)\end{array}$ & $\begin{array}{c}\text { Additional } \\
\text { value } \\
\%\end{array}$ \\
\hline 0 & 0 & 1561 & 0 & 100.00 & 100.00 \\
0.2 & 545 & 1196 & 14762 & 46.61 & 37.18 \\
0.4 & 799 & 1000 & 20251 & 17.02 & 10.46 \\
0.6 & 935 & 879 & 22370 & 8.77 & 3.26 \\
0.8 & 1017 & 796 & 23099 & 5.21 & 0.42 \\
1 & 1070 & 734 & 23195 & 3.46 & 0.00 \\
1.2 & 1107 & 687 & 22977 & 2.44 & 0.00 \\
1.4 & 1134 & 649 & 22597 & 1.76 & 0.00 \\
1.6 & 1154 & 617 & 22134 & 1.30 & 0.00 \\
1.8 & 1169 & 590 & 21631 & 1.03 & 0.00 \\
2 & 1181 & 566 & 21114 & 0.85 & 0.00 \\
2.2 & 1191 & 546 & 20597 & 0.59 & 0.00 \\
2.4 & 1198 & 528 & 20090 & 0.50 & 0.00 \\
2.6 & 1204 & 512 & 19600 & 0.42 & 0.00 \\
2.8 & 1209 & 497 & 19129 & 0.33 & 0.00 \\
3 & 1213 & 484 & 18679 & 0.25 & 0.00 \\
3.2 & 1216 & 472 & 18251 & 0.16 & 0.00 \\
3.4 & 1218 & 461 & 17845 & 0.16 & 0.00 \\
3.6 & 1220 & 451 & 17459 & 0.16 & 0.00 \\
3.8 & 1222 & 442 & 17094 & 0.08 & 0.00 \\
4 & 1223 & 434 & 16747 & & \\
5 & 1225 & 399 & 15263 & MSY = & $1225 \mathrm{t}$ \\
6 & 1224 & 373 & 14104 & & \\
\hline
\end{tabular}

\section{The relative $Y / R$ model $\left(Y^{\prime} / R\right)$}

The Beverton and Holt yield per recruit $(\mathrm{B} / \mathrm{Y})$ analysis and the different Y/R values obtained plotted against respective $F$ values for $S$. choprai show that the present exploitation rate, $(E) 0.59$ is a little below the optimum exploitation rate ( $\left.E_{\max }=0.646\right)$. The $E-_{0.1}$ was estimated as 0.6159 and $E_{-0.5}$ as 0.3672 . An increase in effort by $100 \%$ from the present effort enhance $\mathrm{Y} / \mathrm{R}$ by only $10.4 \%$ and further increase in effort will lead to lesser percentage of increase in Y/R. Here also it was seen that there would not be any significant improvement in the yield with an increase in fishing mortality (increase in fishing effort).

The yield isopleth for $S$. choprai revealed that the increase in the current level of age at capture ( 0.75 years) as well as an increase in effort of present fishing effort $(F)$ will not result in significant improvement in the yield of $S$. choprai along Mangalore-Malpe coast. To understand the impact of increasing the cod-end mesh size on yield and biomass, Y/R and 
B/R of $S$. choprai was estimated with present $T_{c}$ ( 0.75 years) and a higher $T_{c}$ (1.0 year). Y/R and B/R plotted against various fishing efforts (Fig. 5) showed that in all effort levels, the $\mathrm{Y} / \mathrm{R}$ was high with present $T_{c}$ and biomass also did not show any significant improvement by using higher $T_{c}$.

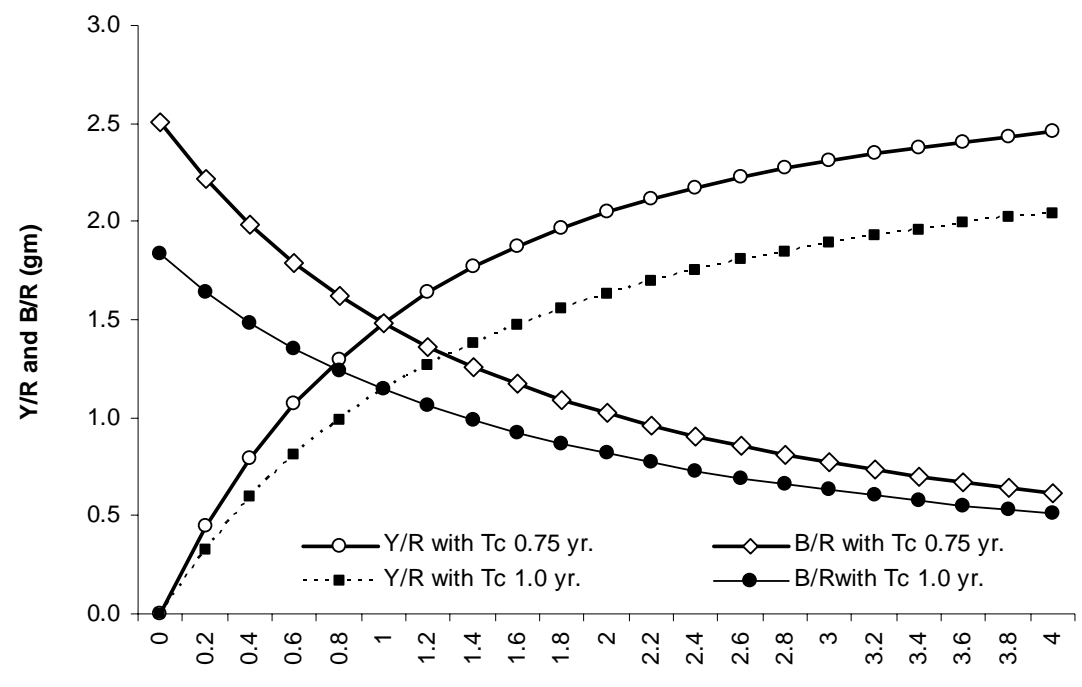

Fishing effort multiplier

Figure 5. Y/R and B/R as a function of fishing mortality in $S$. choprai with different $T_{c}$ values

\section{Marketing and disposal}

$S$. choprai has a high demand in both domestic and export markets. During 2003-2004, the average annual whole-sale price was Rs 30 to 40 per $\mathrm{kg}$. Considering an average price of Rs 30 per $\mathrm{kg}$, as the value realized, S. choprai fishery had contributed about US\$ 1.2 million (Rs 60 million) to the fishery economy of the coast during 2003-2004.

\section{Discussion}

During the past 40 years of trawling history at Karnataka, gradual changes have occurred especially in the depth of operation, duration of operation per fishing trip, and species composition of the landing. In the early sixties the depth of operation was up to 10 to $20 \mathrm{~m}$ (Kuthalingam et al. 1966) and by 1985-1995, the depth of operation was extended up to 100 
m, during which period the fishery of $S$. choprai also emerged. Hashimi et al. (1978), Harkantra et al. (1980), Kidwai et al. (1981) and Shankar and Karbassi (1992) found that there is a strip of sandy bottom off South Karnataka extending from a depth of 50 to $200 \mathrm{~m}$, and this type of sandy bottom is not seen anywhere else in the west coast of India and the fishing ground for $S$. choprai falls within this region (60 to $100 \mathrm{~m}$ ). This unique sandy bottom may be providing an ideal habitat for the congregation of burrowing species like $S$. choprai and supports unusually high catch of this species.

$S$. choprai is widely distributed in the Indo-Pacific, from eastern coast of Africa, Madagascar, Gulfs of Suez and Arabia, Pakistan, India, Malaysia, Philippines, Indonesia, Taiwan, Thailand and northeast and northwest Australia (De Freitas 1985; Tirmizi 1972; Crosnier 1989; Aravindakshan and Karbari 1994; Dall 1999) but the population observed in the mid-shelf off the West coast of India is unique in terms of quantity. The present study revealed that $S$. choprai is caught in good quantity only during the night, which shows that the species is nocturnal in habit. During day time these shrimps were found to burrow deep into the sand. A similar behaviour was reported for $S$. acuminata along the continental slope off French Guinea (Gueguen 1998).

Analyzing the trend of the fishery from this stratum revealed that the catch and catch per unit effort of the species increased rapidly until 2002. During 2003 the mean size of the males and females were 74.7 and $86.7 \mathrm{~mm}$, respectively, then reduced to 72.0 and $82.7 \mathrm{~mm}$, respectively, in 2004. The increase in CPU (catch per unit) of shrimps with increasing effort shows that the ground is virgin and there is more potential to be tapped. But the sudden decline of the resource in total catch, catch per unit coupled with a reduction of mean size from these fishing grounds requires closer monitoring of the stock and their exploitation. A similar trend of a sudden decline of a fishery after increasing for some period was reported also in the case of the deep sea shrimps, Aristeus alcockii and Heterocarpus spp. along the south Kerala coast by Nandakumar et al. (2001). The drastic reduction in overall catch and catch rate, in the deep sea shrimp fishery during 2000-2001 seasons was attributed to the over-exploitation of the virgin fishing ground and to the low fecundity of deep sea shrimps. The relative $Y / R$ showed that the $E_{\max }$ of 0.65 against the present $E$ of 0.59 indicates further scope of increasing the fishing effort in $S$. choprai. However, the Thompson and Bell model indicated that any subsequent addition of effort from the present level, will give comparatively very low additional yield and the present fishery stands at the MEY level. According to 
this model, it appears that there is no scope for increasing the fishing effort to get higher economic yield. From stock assessment studies on $M$. monoceros from the west coast of India, Nandakumar and Srinath (1999) stated that in a multi-species fishery it is rather difficult to make harvesting strategies exclusive to a particular stock. However, it is imperative and advisable to monitor the trend of the landings from the exploited stock of multi-species fisheries in order to assess their status. Close observation of the landing of $S$. choprai in the multi-stock landing and limiting the catch of the species to its estimated MSY level can be suggested as a management measure to sustain its fishery from this unique fishing ground.

\section{Conclusion}

Even though the average landing during the period of study was below the estimated MSY level the reduction in mean size and the reduction in the modal class contributing the fishery indicate that the stock is already subjected to heavy fishing pressure and serious damage is done on the stock, which is evident from the landing from previous years especially during 2002, during which the catch was about three times that of the estimated MSY.

\section{Acknowledgements}

The first author is thankful to ICAR, New Delhi for granting him study leave to carry out this work and to Prof. (Dr). Mohan Joseph Modayil, Director, CMFRI, Kochi and Prof. (Dr). P. Kesavanath, Dean, College of Fisheries, Mangalore for the facilities and their constant support.

\section{References}

Alagaraja, K. 1984. Simple methods for estimation of parameters for assessing exploited fish stock. Indian Journal of Fisheries 31(2): 177-208.

Aravindakshan, M. and J.P. Karbari. 1994. Studies on the fishery and biology of ridgeback shrimps, Solenocera choprai, Nataraj, occurring off Maharashtra coast. Journal of Marine Biological Association of India 36(1\&2): 96-99.

Beverton, R.J.H. and S.J. Holt. 1964. Tables of yield functions for fishery assessment. FAO Fisheries Technical Paper 38. 49 pp. 
Chan, T.Y. 1998. Shrimps and Prawns. In: FAO identification guide for fishery purposes - The Living Marine Resources of the Western Central Pacific, Vol. 2, Cephalopods, Crustaceans, Holothurians and Sharks. (ed. K.E. Carpenter and V.H. Niem), pp. 827-1155.

Crosnier, A. 1989. Benthesicymidae, Aristidae, Solenoceridae (Crustacea: Penaeoidea). Resultats des campagnes Musorstom. Vol. 5. (ed. J. Forest), pp. 37-67. Memoirs du Museum d'Histoire Naturelle, (a) Zoologie 144.

Dall, W. 1999. Australian species of Solenoceridae (Penaeoidea: Decapoda). Memoirs of Queensland Museum 43: 553-587.

De Freitas, A.J. 1985. The penaeoidea of South East Africa II. The families Aristidae and Solenoceridae. Oceanographic Research Institute (Durban) Investigation report 57: 1-69.

Dineshbabu, A.P. and J.K. Manissery. 2007. Morphometric relationship and growth of the 'ridge back shrimp' Solenocera choprai (Decapoda/ Crustacea) from Mangalore (southwest coast of India). Indian Journal of Marine Sciences 36(1): 65-70.

Gayanilo Jr. F.C. and D. Pauly. (eds). 1997. The FAO-ICLARM stock assessment Tools (FiSAT) reference manual, FAO Computerized Information Series 8, (Fisheries), FAO, Rome, $262 \mathrm{pp}$.

Gueguen, F. 1998. Biology of the deep-water shrimp Solenocera acuminata in French Guiana. Comptes Rendus de 1 Academie des Sciences Serie iii- Sciences de la Vie-Life Sciences 321: 385-394.

Harkantra, S.N., A. Nair, Z.A. Ansari and A. H. Parulekar. 1980. Benthos of the shelf region along the west coast of India. Indian Journal of Marine Sciences 9: 106-110.

Hashimi, N.H., R.M. Kidwai and R.R. Nair. 1978. Mean-size and coarse-fraction studies of sediments between Vengurla and Mangalore on the west coast of India. Indian Journal of Marine Sciences 7: 231-238.

Kidwai, R.M., R.R. Nair and N.H. Hashimi. 1981. Heavy minerals in the sediments on the outer continental shelf between Vengurla and Mangalore on the West Coast of India. Journal of Geological Society of India 22: 32-38.

Kuthalingam, M.D.K., S. Ramamurthy, K.K.P. Menon, G.G. Annigeri and N.S. Kurup. 1966. Prawn fishery of Mangalore zone with special reference to fishing grounds. Indian Journal of Fisheries 12(2): 546-554.

Nandakumar, G and M. Srinath. 1999. Stock assessment of Metapenaeus monoceros (Fabricius) from Cochin waters. Indian Journal of Fisheries 46: 221-226

Nandakumar, G., K.N. Rajan. and K. Chellappan. 2001. Is deep sea prawn fishery of Kerala sustainable? Marine Fisheries Information Service, T\&E Series (Central Marine Fisheries Research Institute) 170: 5-9.

Pauly, D. 1983. Length converted catch curves. A powerful tool for fisheries research in the tropics (Part I). ICLARM Fishbyte 1: 9-13.

Radhakrishnan, E.V, M.K. Manissery and G. Nandakumar. 2007. Status of research on crustacean fisheries. In: Status and Perspectives in Marine Fisheries Research in India. Central marine Fisheries Research Institute, Kochi. 135: 172.

Shankar, R. and A.R. Karbassi. 1992. Sedimental evidence for paleobeach off Mangalore, West coast of India. Journal of Geological Society of India 40: 241-252.

Srinath, M. 1990. Letters to the editor. ICLARM, Fishbyte 9: 2.

Thompson, W.F and F.H. Bell. 1934. Biological statistics of the pacific halibut fishery. 2. Effect of changes in intensity upon total yield and yield per unit of gear. Report on International Fisheries (Pacific Halibut) Commission. 8. 48 pp.

Tirmizi, N.M. 1972. An illustrated key to the identification of Northern Arabian Sea penaeids. Pakistan Journal of Zoology 4: 185-211. 